УДК 903.224

https://doi.org/10.24852/2587-6112.2020.6.387.392

\title{
ДВА НАКОНЕЧНИКА ПИК ИЗ СОБРАНИЯ НИЖЕГОРОДСКОГО ГОСУДАРСТВЕННОГО ИСТОРИКО-АРХИТЕКТУРНОГО МУЗЕЯ-ЗАПОВЕДНИКА ${ }^{1}$
}

\author{
(С2020 г. Б.А. Илюшин
}

Статья вводит в научный оборот два наконечника пик из собрания Нижегородского историкоархитектурного музея заповедника. Оба насажены на поздние древки. В фонды музея данные экземпляры поступили от сына известного фотографа и художника А.О. Карелина (1837-1906); место приобретения их прежним владельцем неизвестно. Наконечники - железные, втульчатые, с трёхгранным в сечении пером шиловидной формы и «яблоком» на шейке пера. Втулка одного из наконечников имеет две пожилины (оттяжки) - металлические полоски с отверстиями для крепёжных гвоздей. Для датировки наконечников были рассмотрены их конструктивные особенности и найдены близкие аналогии. Наиболее вероятная датировка и атрибуция - Россия, конец XVI - первая половина XVII вв., лёгкая кавалерийская пика или оружие полков Нового строя (пикинёры, солдаты). Наличие аналогий в казахских материалах XVII - первой половины XIX вв. позволяет предполагать также позднее «восточное» происхождение наконечников.

Ключевые слова: Российское государство, XVI-XVII вв., военное дело, вооружение, наконечники, пики.

\section{TWO PIKE-HEADS FROM THE COLLECTION OF NIZHNY NOVGOROD STATE HISTORICAL AND ARCHITECTURAL MUSEUM-RESERVE ${ }^{2}$}

\section{B. A. Ilyushin}

The paper introduces into scientific discourse two pike-heads from the collection of Nizhny Novgorod State Historical and Architectural Museum-Reserve (Nizhny Novgorod, Russia). Both of them are fitted on shaft of later historical periods. These items were deposited in the museum collection by the son of a renowned photographer and artist A. O. Karelin (1837-1906); the source of their acquirement by the former owner is unknown. Tips of the pikes are made of iron and feature sockets and a blade with a triangular cross-section of an awl shape and an "apple" on the neck of the blade. The socket of one of the tips has two "veins" (backlines) - metal strips with holes for fixing nails. For dating of the pike-heads, their design features considered, and close counterparts were found. Their most probable dating and attribution are proposed as Russia, late 16th - first half of 17 th centuries, light cavalry pike or the weapons of New order regiments (pikemen, soldiers). The presence of counterparts in Kazakh materials of the 17th -first half of 19th centuries allows the author also to assume later "Oriental" origins of the spearheads.

Keywords: Russian state, 16th-17th centuries, warfare, armament, tips of the pikes.

Растущий в последние годы интерес к военному делу Московского царства XV-XVII вв. и его соседей, появление исследований по частным (Бобров, Филиппович, 2015; Бобров, Худяков, 2010; Комаров, 2016, дата обращения: 26.04.2019; Несин, 2019; Шиндлер, 2019) и общим (Багрин, 2013; Двуреченский, 2015; Пенской, 2008) вопросам делает актуальным введение в научный оборот новых материалов из музейных собраний, частных коллекций и археологических памятников.
Среди хранящихся в собрании Нижегородского государственного историко-архитектурного музея-заповедника (НГИАМЗ) предметов вооружения, происходящих из разных источников, имеется несколько экземпляров наконечников длиннодревкового оружия, до настоящего времени не становившихся объектом специального научного исследования. Целью нашей статьи является введение в научный оборот двух экземпляров наконечников пик из собрания НГИАМЗ, описание их

\footnotetext{
Исследование проведено в рамках реализации Государственного задания Минобрнауки России в сфере научной деятельности (проект № FSUS-2020-0021)

The study was carried out as part of the implementation of the State Assignment of the Ministry of Education and Science of Russia in the field of scientific activity (project No. FSUS-2020-0021)
} 
морфологии и системы оформления, датировка и атрибуция

Рассмотренные экземпляры находятся в хорошем состоянии, но имеют заметный налёт ржавчины. В настоящее время они насажены на поздние древки. По материалу изготовления наконечники относятся к классу железных, по способу насада на древко - к отделу втульчатых, по сечению пера - к группе треугольных, по форме пера - типу шиловидных. По конструктивным особенностям втулки можно выделить два варианта.

Вариант 1. Шиловидный наконечник с оттяжками (пожилинами) на втулке.

Экземпляр № 1. Инвентарный номер ГОМ 7259-1 ОР 389 (рис. 1).

Вес предмета определить не удалось, поскольку наконечник насажен на древко. Общая длина наконечника - 60 см. Длина пера - 26 см. Ширина пера в нижней широкой части - 2 см, в средней части (в 13,5 см от острия) - 1,8 cм, в верхней части (в 5 см от острия) - 1,2 см. Максимальная толщина пера - 2 см. Перо резко затуплено. Пропорции пера (ширина у основания к длине) - 1 к 13. Высота шейки - 1,8 см, ширина $-1,7$ см. На шейке имеется декоративный элемент - «яблоко» диаметром 3,2 см и высотой 1,4 см. Снизу яблоко не приварено к шейке. Длина втулки - 10,8 см. Диаметр втулки в верхней части $-1,8$ см, в средней части (в 5,4 см от края) - 3,1 см, в нижней части $-4,1$ см. Толщина стенок втулки - 0,5 см. На втулке имеются слабые следы заваренного шва, благодаря чему можно выделить лицевую и тыльную стороны наконечника (при этом перо обращено на лицевую сторону ребром, а на тыльную - гранью). От края втулки отходят две оттяжки, или пожилины (приваренные металлические полосы), с тремя отверстиями для гвоздей в каждой. Расположение оттяжек неровное относительно шва втулки: левая оттяжка приварена в 1 см от шва; правая - на противоположной стороне втулки. Длина левой оттяжки $-22,5$ см, правой -22 см; ширина обеих оттяжек из-за неровности краёв варьирует от 1,3 до 1,6 см. Расположение отверстий с гвоздями крепления в оттяж-

Автор выражает благодарность Гусеву А.Д., Дремину А.Н., Шавенкову П.В. и остальному персоналу и руководству Нижегородского государственного историко-архитектурного музея заповедника за предоставление доступа к музейным экспонатам, изготовление и предоставление их фотографий.

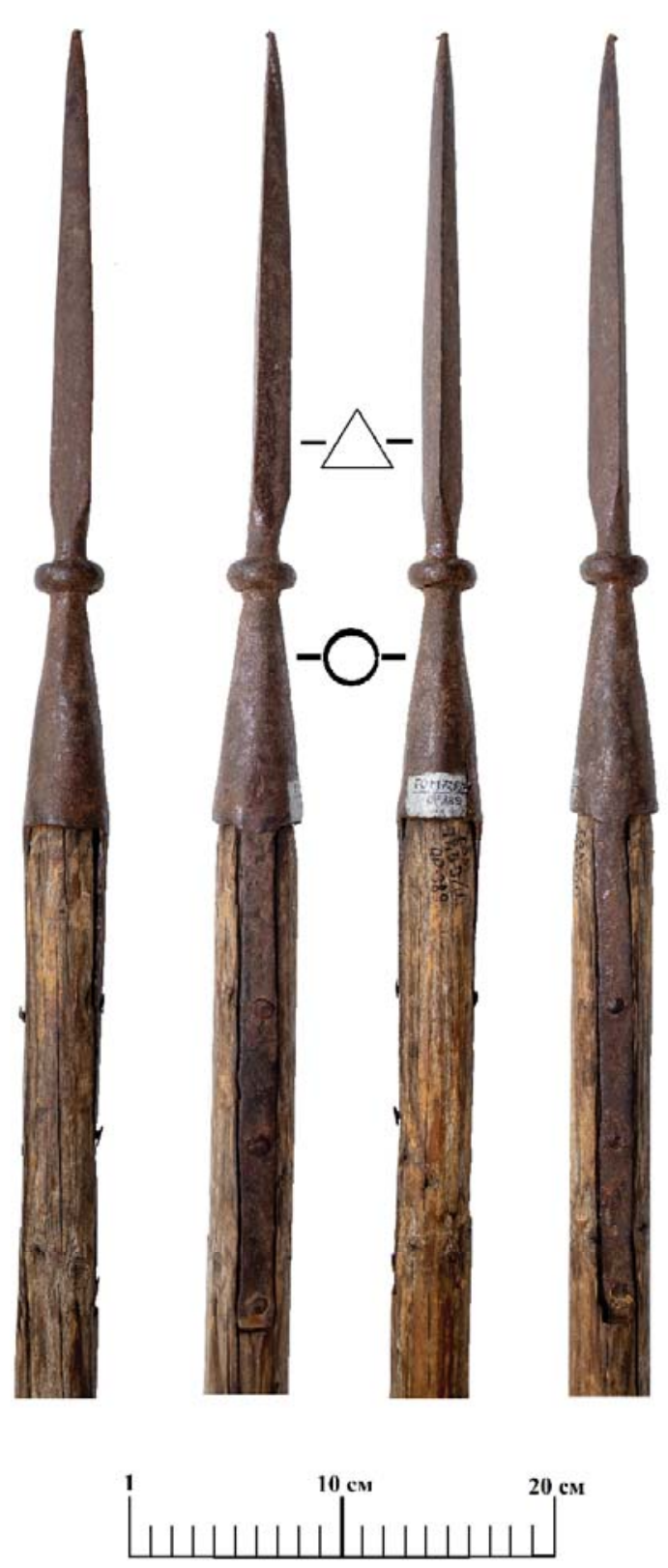

Рис. 1 (фото). Наконечник № 1 (лицевая, левая, тыльная и правая стороны), инвентарный номер ГОМ 7259-1 ОР 389 (НГИАМЗ).

Fig. 1. Tip No. 2 (front, left, back and right sides), inventory number GOM 7259-1. OR 389 (Nizhny Novgorod State Historical and Architectural Museum-Reserve).

ках (от края): в левой - 0,4 см, 7,5 см, 13,5 cм; в правой -1 см, 7,7 см, 13,7 см.

Пожилины служили для более плотной фиксации наконечника на древке, что было особенно важно при нанесении сильного удара на полном скаку и по защищённому противнику. Кроме того, пожилины предохраняли значительную часть древка от повреждения. Известно, что для укрепления древка в позднее Средневековье стали использовать- 
ся такие конструктивные элементы, как отрез (фактически небольшой палаш), обвивающая древко толстая проволока, металлические кольца и др. Пожилины широко использовались в Центральной и Средней Азии, калмыками, башкирами, а в XIX в. этот элемент стал присутствовать в унифицированном варианте российской кавалеристской пики (Бобров, 2013 , с. 98-100). На более ранних образцах пожилины также присутствовали (Учение..., 1904, с. 104), но не регулярно.

Вариант 2. Шиловидный наконечник без оттяжек на втулке.

Экземпляр № 2. Инвентарный номер ГОМ 7259-2 ОР 391 (рис. 2). Вес предмета определить не удалось, поскольку наконечник насажен на древко. Общая длина наконечника 33,5 см. Длина пера - 23,2 см. Ширина пера в нижней широкой части -2 см, в средней части (в 11,5 см от острия) - 1,8 см, в верхней части (в 5 см от острия) - 1,3 см. Максимальная толщина пера -2 см. Перо затуплено и загнуто на тыльную сторону (в сторону шва втулки). Пропорции пера (ширина у основания к длине) - 1 к 11. Высота шейки $-1 \mathrm{~cm}$, ширина - 1,6 см. На шейке имеется декоративный элемент - сильно уплощённое «яблоко» диаметром 2,7 см и высотой 1,1 см. Длина втулки - 9,5 см. Диаметр втулки в верхней части $-1,4$ см, в средней части (в 4,7 см от края) $-2,7$ см, в нижней части $-4,4$ см. Толщина стенок втулки - 0,5 см. На втулке имеются слабые следы заваренного шва, благодаря чему можно выделить лицевую и тыльную стороны наконечника (при этом перо обращено на лицевую сторону ребром, а на тыльную - гранью). По бокам втулки, со смещением ко шву, имеются два отверстия с крепёжным гвоздём. Левое расположено в 1,6 см от края втулки, правое - в 1,3 см.

Оба наконечника были переданы в собрание НГИАМЗ после 1917 г. сыном известного художника и фотографа А.О. Карелина (18371906), интересовавшегося российскими древностями. Место приобретения фотографом наконечника неизвестно.

Узкие гранёные наконечники пик использовались для пробивания доспехов и являлись оружием преимущественно конных воинов. Это предполагает бытование пик в основном на западных и северо-западных рубежах, в военных действиях против шведов, литовцев и поляков, но не против степняков, среди которых защитное вооружение в XV-XVII вв. становится очень редким (Горе-

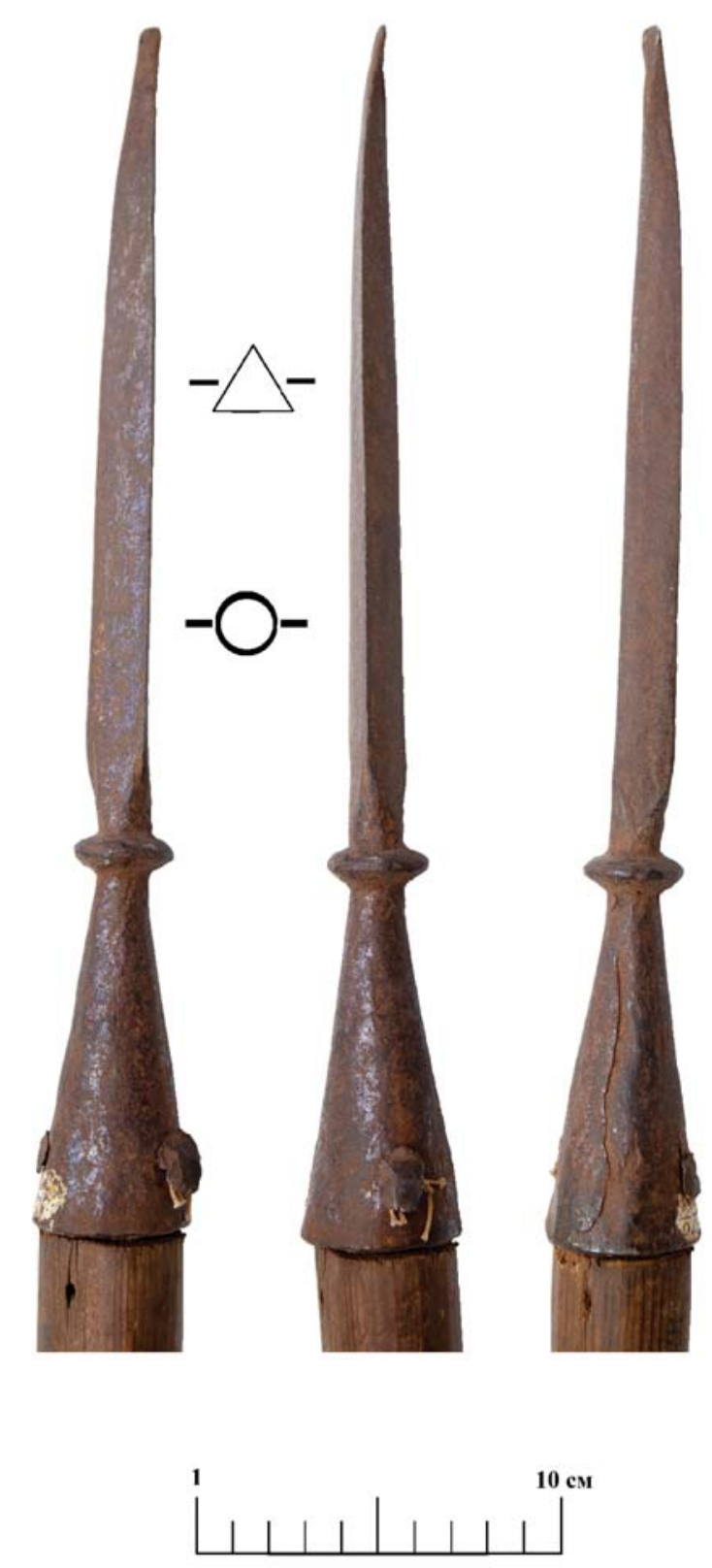

Рис. 2 (фото). Наконечник № 2 (лицевая, правая и тыльная стороны), инвентарный номер ГОМ 7259-2 ОР 391 (НГИАМЗ).

Fig. 2. Tip No. 2 (front, right sides and back), inventory number GOM 7259-2. OR 391 (Nizhny Novgorod State

Historical and Architectural Museum-Reserve).

лик, 2011, с. 56-57). Для нанесения ущерба незащищённому доспехом противнику чаще использовались рогатины - длиннодревковое оружие с массивным наконечником и широким пером.

Отметим также, что использование термина «пика» в отношении русского оружия достаточно условно. Слово «пика» имеет французское происхождение; восточнославянским же термином для обозначения такого вида наконечников является, видимо, «списа» (поздние 
варианты - «шписа», «спица») (Чубинский, 2016 , с. 331-332; Устав..., 1777, с. 6-7). Однако уже в XVII в. в Российском государстве был в редком употреблении термин «пика» (Учение..., 1904, с. 108). При этом в источниках имеется некоторая неопределённость в вопросе использования того или иного термина (а длинные пики пикинёров нередко вовсе именовались копьями) (Чубинский, 2016, с. 331-332).

O российских пиках XVII-XIX вв. писал В.А. Городцов, отмечая, что в книге 1647 г. «Учение и хитрость ратного строения пехотных людей» имеются указания о наиболее приемлемой конструкции пик, включающей две «полосы железные» с конца, с помощью которых наконечник крепится к древку. Сам В.А. Городцов именует эти полосы (отмеченные нами пожилины или оттяжки) скобами или тяжами (Городцов, 1913, с. 4-7).

Позднесредневековые пики были рассмотрены в работах А.Н. Кирпичникова и О.В. Двуреченского.

А.Н. Кирпичников отмечает, что пика появляется на вооружении древнерусских воинов ещё с IX в., а происхождение этого вида длиннодревкового оружия он связал со степью. В XII-XIII вв. пики становятся одним из самых массовых видов такого оружия (Кирпичников, 1966, с. 15-16). Наибольшее же распространение пики получили в XIV начале XV вв. в связи с утяжелением доспеха (Двуреченский, 2015, с. 70). И позже, по мере значительного сокращения доли длиннодревкового оружия в русском арсенале, что было связано с «ориентализацией» военного дела, пики не выходят из употребления, хотя их использование также сокращается, и, например, С.К. Богоявленский упомянул их в своей работе о вооружении XVI-XVII вв. в основном в качестве оружия ратников полков «нового строя» (Богоявленский, 1938, c. 280-281).

Рассмотренные нами наконечники по своим конструктивным особенностям схожи с теми, что А.Н. Кирпичников отнёс к типу $\mathrm{V}$, однако эти более ранние образцы имеют четырёхгранное сечение и, как правило, лишены яблока (Кирпичников, 1966, с. 15). Отметим, что «яблоко» являлось декоративным элементом. К нему могли крепиться бахрома или кисть (Городцов, 1913, с. 19; Двуреченский, 2015, с. 68).

О.В. Двуреченский, корректировавший применявшуюся к более раннему периоду классификацию наконечников, охарактеризовал такие пики, как копья с наконечником в виде стержня, треугольные, ромбические или четырёхугольные в сечении и с воронковидной втулкой. Среди них он выделил 6 вариантов. Пики из НГИАМЗ можно отнести к варианту 1В (в вытянутой шейкой и яблоком). Ранние образцы таких наконечников бытовали в первой половине XVI в. и были украшены узором. Во второй половине XVI - середине XVII в. они теряют украшения. Длина таких наконечников равнялась 18,7-32 см, длина пера - 8,7-18 см. Автором рассмотрены образцы из Москвы, Тушинского лагеря, Волока Ламского, Орешка (Двуреченский, 2015, с. 72-74).

Таким образом, исходя из рассмотренных аналогий, охарактеризованные нами наконечники пик можно уверенно датировать концом XVI - первой половиной XVII вв. Данный тип имел относительно широкое распространение у ратников Российского государства указанного времени, а также застал наметившееся под влиянием калмыков расширение использования длиннодревкового оружия конницей во второй трети XVII в. (Бобров, 2013, с. 245-246).

\section{ЛИТЕРАТУРА}

Багрин E.A. Военное дело русских на восточном пограничье России в XVII в.: Тактика и вооружение служилых людей в Прибайкалье, Забайкалье и Приамурье. СПб.: Нестор-История, 2013. 288 с.

Бобров Л.А. К вопросу о комбинированном длинно-древковом оружии кочевников Центральной и Средней Азии XVIII - середины XIX века // Военное дело средневековых народов Южной Сибири и Центральной Азии / Отв. ред. Ю. С. Худяков, С. Г. Скобелев. Новосибирск: Изд-во ИАЭТ СО РАН, 2013. С. 96-105.

Бобров Л.А. Казахская тактика ведения боя в конном строю в конце XV-XVI веках // Война и оружие: Новые исследования и материалы. Труды Третьей международной научно-практической конференции 15-17 мая 2013 г. Ч. І. СПб.: ВИМАИВиВС, 2013. С. 231-258.

Бобров Л.А., Филиппович Ю.А. Копейный наконечник с S-образными «отрожками» из Сузунского района Новосибирской области // Вестник НГУ. Серия: История, филология. 2015. Т. 14. № 3. С. 93-99. 
Бобров Л.А., Худяков Ю.С. Копья с завитками - отрожками как пример взаимовлияния русских, тюркских и монгольских военно-культурных традиций на территории Южной Сибири в XVII-XVIII веках // Вестник НГУ. Серия: История, филология. 2010. Т. 9. № 3. С. 174-181.

Богоявленский С.К. Вооружение русских войск в XVI-XVII вв. // Исторические записки. Т. 4. / Отв. ред. Б. Д. Греков М.: Изд-во АН СССР, 1938. С. 258-283.

Горелик М.В. Монгольская латная конница и её судьба в исторической перспективе // Военное дело Золотой Орды. Проблемы и перспективы изучения / Отв. ред. И. М. Миргалеев. Казань: Изд- во: ИИ им. Ш. Марджани АН РТ, 2011. С. 47-58.

Городиов B.A. Описание холодного оружия Исторического музея / Труды Исторического музея. М.: Синодальная типография, 1913. $38 \mathrm{c}$.

Двуреченский О.В. Холодное оружие Московского государства XV-XVII веков. Тула: Изд-во Государственного музея-заповедника «Куликово поле», 2015. 498 с.

Кирпичников А.Н. Древнерусское оружие. Копья, сулицы, боевые топоры, булавы, кистени. IX-XIII вв. Вып. ІІ / САИ. Вып. Е1-36. М.-Л.: Наука, 1966. 181 с.

Комаров O.B. Изучение комплекса вооружения дворянского войска XVI в. и документальные источники // История военного дела: исследования и источники. 2016. № 7. С. 392-460. URL: http://www. milhist.info/2016/02/03/komarov_1 (дата обращения: 26.04.2019)

Несин М.A. Доспех-призрак (взгляд историка на проблемы оружиеведения) // Novogardia. 2019. № 1. C. $348-384$.

Пенской В.В. От лука к мушкету. Вооруженные силы Российского государства во 2-й половине XVXVII вв.: проблемы развития. Белгород: Изд-во БелГУ, 2008. 256 с.

Устав ратных, пушечных и других дел, касающихся до воинской науки. Ч. II. СПб., 1777. 231 с.

Учение и хитрость ратного строения пехотных людей. 1647 год. СПб.: Тип. "Бережливость", 1904. $357 \mathrm{c}$.

Чубинский А.Н. К вопросу о русских названиях древкового средневекового оружия. Рогатины, копья, сулицы и совни // Война и оружие: новые исследования и материалы. Материалы Седьмой Международной научно-практической конференции 18-20 мая 2016 года. Часть V. СПб.: ВИМАИВиВС, 2016. C. $310-340$.

Шиндлер О.B. К вопросу о методологии исследования московских доспехов XV-XVII веков // Novogardia. 2019. № 1. С. 323-347.

\section{Информация об авторе:}

Илюшин Борис Анатольевич, кандидат исторических наук, младший научный сотрудник Лаборатории гуманитарных исследований, Новосибирский государственный университет (г. Нижний Новгород, Россия); arunta-desert@yandex.ru

\section{REFERENCES}

Bagrin, E. A. 2013. Voennoe delo russkikh na vostochnom pogranich'e Rossii v XVII v.: Taktika $i$ vooruzhenie sluzhilykh lyudei v Pribaikal'e, Zabaikal'e i Priamur'e (Russian Military Affairs on the Eastern Border of Russia in the 17th Century: Tactics and Weapons of Servicemen in the Baikal Region, Transbaikalia and Amur Region). Saint Petersburg: "Nestor-Istoriia" Publ. (in Russian).

Bobrov, L. A. 2013. In Voina i oruzhiye: Novyie issledovaniia i materialy. Trudy Tretyey Mezhdunarodnoy nachno-prakticheskoy konferentsii 15-17 maya 2013 goda. Chast' I (War and Weapons: New Studies and Materials. Proceedings of the Third International Scientific-Practical Conference, May 15-17, 2013. Part I). Saint Petersburg: Military-Historical Museum of Artillery, Engineer and Signal Corps, 231-258 (in Russian).

Bobrov, L. A. 2013. In Khudyakov, Yu. S., Skobolev, S. G. (eds.). Voennoe delo srednevekovykh narodov Yuzhnoi Sibiri i Tsentral'noi Azii: sbornik nauchnyh trudov (Military Affairs of the Medieval Peoples of Southern Siberia and Central Asia: Collection of Scientific Papers). Novosibirsk: Siberian Branch of the Russian Academy of Sciences, Institute for Archaeology and Ethnography, 96-105 (in Russian).

Bobrov, L. A., Filippovich Yu. A. 2015. In Vestnik Novosibirskogo Gosudarstvennogo universiteta. Istoriia, filologiya (Bulletin of the Novosibirsk State University: History, Philology) 14 (3), 93-99 (in Russian).

Bobrov, L. A., Khudyakov Yu. S. 2010. In Vestnik Novosibirskogo Gosudarstvennogo universiteta. Istoriia, filologiya (Bulletin of the Novosibirsk State University: History, Philology) 9 (3), 174-181 (in Russian).

Bogoyavlenskiy, S. K. 1938. In Grekov, B. D. (ed.). Istoricheskie zapiski (Historical Notes) 4. Moscow: USSR Academy of Sciences, 258-283. (in Russian). 
Gorelik, M. V. 2011. In Mirgaleev, I. M. (ed.). Voennoe delo Zolotoi Ordy. Problemy i perspektivy izucheniia (Military Affairs of the Golden Horde. Study Issues and Prospects). Kazan: Institute of History named after Sh. Mardzhani, Tatarstan Academy of Sciences Publ., 47-58 (in Russian).

Gorodtsov, V. A. 1913. Opisanie kholodnogo oruzhiya Istoricheskogo muzeya (Description of Melee Weapons of the Historical Museum). Trudy Istoricheskogo muzeya (Proceedings of the Historical Museum). Moscow: Synodal Printing House Publ. (in Russian).

Dvurechensky, O. V. 2015. Kholodnoe oruzhie Moskovskogo gosudarstva XV-XVII vekov (Melee Weapons of the Moscow State of the 15th-17th cc.). Tula, "Kulikovo Pole" State Museum-Reserve Publ. (in Russian).

Kirpichnikov, A. N. 1966. Drevnerusskoe oruzhie (Early Russian Weapons) 2. Kop'ia, sulitsy, boevye topory, bulavy, kisteni IX-XIII vv. (Spears, Lances, War Axes, Maces, Flails of 9th-13th Centuries). Series: Svod Arkheologicheskikh Istochnikov (Corpus of Archaeological Sources) E1-36. Moscow; Leningrad: "Nauka" Publ. (in Russian).

Komarov, O. B. 2016. In Istoriya voyennogo dela: issledovaniya i istochniki. (The History of Warfare: Studies and Sources) 7, 392-460 Available at: http://www.milhist.info/2016/02/03/komarov_1 (Accessed: 26.04.2019). (in Russian).

Nesin, M. A. 2019. In Novogardia. 1, 348-384. (in Russian).

Penskoi, V. V. 2008. Ot luka k mushketu. Voorushonnye sily Rossiyskogo gosudarstva vo 2-y polovine XVXVII vv.: problem razvitiya (From the bow to the musket. The armed forces of the Russian state in the 2nd half of the XV-XVII centuries: problems of development). Belgorod: Publishing house of Belgorod state University. (in Russian)

1777. Ustav ratnyh, pushechnyh I drugih del, kasayushihst'a do voinskih nauk. Chast' I (Code on of Military, Cannon and Other Matters Relating to Military Science) II. Saint-Petersburg. (in Russian).

1904. Ucheniye i hitrost'ratnogo stroyeniya pehotnyh l'udey. 1647 god (Doctrine and Peculiarities of the Military Formation of Infantry Men. 1647). Saint-Petersburg: "Berezhlivost"” Pul. (in Russian).

Chubinskiy, A. N. 2016. In Vojna i oruzhiye: novyje issledovaniya i materialy. Materialy Sed'moy Mezhdunarodnoy nachno-prakticheskoy konferentsii 18-20 maya 2016 goda. Chast'V (War and Weapons: New Studies and Materials. Proceedings of the Seventh International Scientific-Practical Conference, May 18-20, 2016. Part V). Saint Petersburg: Military-Historical Museum of Artillery, Engineer and Signal Corps, 310-340 (in Russian).

Shindler, O. V. 2019. In Novogardia. 1, 323-347. (in Russian).

\section{About the Author:}

Ilyushin Boris A. Candidate of Historical Sciences. Novosibirsk State University, Pirogova str. 1, Novosibirsk, 630090, Russian Federation; arunta-desert@yandex.ru 
УДК 903.22

https://doi.org/10.24852/2587-6112.6.393.404

\title{
ШЛЕМ ОЙРАТСКОГО ВОИНА ИЗ СОБРАНИЯ АКМОЛИНСКОГО ОБЛАСТНОГО ИСТОРИКО-КРАЕВЕДЧЕСКОГО МУЗЕЯ 1
}

\author{
(С2020 г. Л.А. Бобров, А.К. Кушкумбаев
}

В статье рассмотрен клепаный железный шлем (ГИН 148), хранящийся в Акмолинском областном историко-краеведческого музее (АОИКМ), г. Кокшетау, Республика Казахстан. Первоначально шлем был атрибутирован казахстанскими исследователями, как «русский», а впоследствии, как «казахский». Проведенный типологический анализ позволил уточнить датировку и атрибуцию наголовья. По материалу изготовления шлем ГИН 148 из собрания АОИКМ относится к классу железных, по конструкции тульи - к отделу клепанных, по форме купола - к типу сфероконических. Общая высота наголовья - 24,5 см, диаметр - 21,0 см. Установлено, что шлем ГИН 148 относится к особой группе шлемов ойрато-казахского пограничья периода позднего Средневековья и раннего Нового времени. В настоящее время авторам известно о 18 подобных шлемах, которые происходят с территории Казахстана, Монголии, России (Поволжье, Южная Сибирь) и Северо-Западного Китая. Отличительной особенностью конструкции шлемов серии является клепанная четырехчастная тулья, дополненная «каркасом», состоящим из узких накладок с ровным краем и узкого обруча (или двух обручей), расположенного значительно выше нижней кромки шлема. Анализ А-образных фиксаторов бармицы показал, что они могут быть атрибутированы, как изображение санскритских слогов «mа» (выполненных письмом ланьча), традиционно входивших в состав многих буддийских мантр. Изображения санскритских знаков «та», «от» и др. неоднократно встречаются на предметах защитного вооружения ойратского производства XVII - середины XVIII вв. (шлемах, панцирях и т.д.), хранящихся в российских и иностранных музейных и частных собраниях. Особенности конструкции шлема из АОИКМ, а также наличие в его оформлении буддийской символики, свидетельствуют в пользу того, что данное наголовье было изготовлено ойратскими (джунгарскими или калмыцкими) оружейниками XVII - середины XVIII вв. Весьма вероятно, что впоследствии шлем мог попасть в руки казахских кочевников и применяться в качестве боевого наголовья вплоть до середины XIX в. включительно.

Ключевые слова: Казахстан, ойраты, джунгары, калмыки, ойратский доспех, ойратский шлем.

\section{OIRAT WARRIOR'S HELMET FROM THE AKMOLA REGIONAL HISTORY MUSEUM COLLECTION ${ }^{2}$}

\section{L.A. Bobrov, A.K. Kushkumbaev}

The article provides a detailed analysis of a riveted iron helmet (GIN 148) deposited in the Akmola Regional History Museum (ARHM), Kokshetau, the Republic of Kazakhstan. Initially the helmet was identified as "Russian" by Kazakhstan researchers, and subsequently reclassified as "Kazakh". A typological analysis conducted by the authors has provided more precise dating and attribution of the helmet. The helmet belongs to the class of iron helmets in terms of material, to the riveted class in terms of crown design, and to the spheroconical type in terms of the dome shape. Its total height is $24.5 \mathrm{~cm}$, and the diameter is $21.0 \mathrm{~cm}$. It has been confirmed that the helmet GIN 148 belongs to a special group of helmets of the Oirat-Kazakh borderland of the late Middle Ages or the early Modern times. Currently 18 similar helmets have been identified by researchers, which originate from the territory of Kazakhstan, Mongolia, Russia (Volga region, Southern Siberia) and North-Western China. A distinctive feature of this series of helmets is a riveted four-plate crown supplemented by a "carcass" consisting of narrow overlays with a flat edge and a narrow hoop (or two hoops) fitted much higher than the bottom edge of the helmet. An analysis of the A-shaped chain mesh fixers revealed that they can be attributed to the image of the Sanskrit syllables "ma" (written in Lancha letters), traditionally included in many Buddhist mantras. Images of the Sanskrit signs "ma", "om", etc. have been found on numerous protective weapons of Oirat manufacture (helmets, shells, etc.) dated the 17th - mid-18th centuries and deposited in Russian and foreign museum and private collections. Specific features of the helmet from the Aktobe Regional

1 Исследование проведено в рамках государственного задания в сфере научной деятельности (проект № 33.5677.2017/8.9.

2 The study was conducted within the framework of the state task in the field of scientific activity (project No. 33.5677.2017/8.9. 
Museum of History and Local Lore as well as Buddhist symbols in its design indicate that this headpiece was crafted by Oirat (Jungar or Kalmyk) armourers in the 17th-mid-18th centuries. It is very likely that the helmet could have subsequently fallen into the hands of Kazakh nomads and could been used as a headpiece until the mid-19th century.

Keywords: Kazakhstan, the Oirats, the Dzhungars, the Kalmyks, Oirat armour, Oirat helmet.

Исторический период, охватывающий XVII - первую половину XVIII вв., не случайно именуется в научной литературе «Эпохой малого монгольского (ойратского) нашествия». Это было время последнего масштабного всплеска военно-политической активности монголоязычных кочевников Центральной Азии. В первой половине - середине XVII в. ареал военной активности ойратов включал огромные пространства внутренней Евразии от причерноморских степей на западе до Тибета на востоке, и от лесов Западной Сибири на севере до пустынь Мавераннахра на юге. В конце XVIIв. войска Галдана Бошокту-хана оккупировали большую часть Монголии и вышли к Великой Китайской стене. В первой половине XVIII в. джунгарские хунтайджи контролировали значительную часть Центрального, Южного и Юго-Восточного Казахстана, практически весь Восточный Туркестан и Горный Алтай. В свою очередь западные ойраты (волжские калмыки) стали одним из основных союзников Российского государства в войнах с крымскими татарами и ногаями. Калмыцкие отряды неоднократно вторгались в Крым и земли черкесов, вели боевые действия на территории Правобережной и Левобережной Украины, в причерноморских степях, на Кубани и в степях Западного Казахстана. Под ударами калмыков пала Большая Ногайская орда. Весьма значительный вклад внесли калмыки и в победы российской армии над войсками Крымского ханства и его союзников в военных конфликтах первой половины - середины XVIII в. Таким образом, ойраты сыграли важную роль в исторической судьбе многих народов Восточной Европы, Северного Кавказа, Центральной, Средней и континентальной Восточной Азии (Чимитдоржиев, 1979, с. 6-65; Златкин, 1983, с. 178-209; Цюрюмов, Батыров, 2006, c. 12-78; Тепкеев, 2012, с. 11-84, 112-172, 212-215, 318-341; Бобров, Рюмшин, 2015, с. 357-367). В настоящее время тысячи предметов ойратского вооружения хранятся в музейных и частных собраниях России, Казахстана, Монголии, Китая, Узбекистана, а также США, Великобритании и других стран. Введение их в научный оборот является актуальной науч- ной задачей (Бобров, 2011, с. 3, 4, 17-20, 29, 30).

В Акмолинском областном историкокраеведческого музее (АОИКМ, г. Кокшетау, Республика Казахстан) хранится клепаный железный шлем (ГИН 148) представляющий значительный интерес для отечественных и зарубежных оружиеведов, археологов и военных историков (рис. 1)

Согласно акту приемки-сдачи № 148 (Приложение № 149) от 20 марта 1951 г. рассматриваемый образец защитного вооружения был первоначально атрибутирован, как «Шлем (головной убор древнерусского воина)». В акте также сообщалось, что наголовье имеет плохую сохранность и покрыто ржавчиной.

По данным сотрудников музея, шлем относится к числу случайных находок. Он был обнаружен местными жителями на территории Северного Казахстана (нынешняя Северо-Казахстанская, по другим данным, Акмолинская область Республики Казахстан). К сожалению, иные обстоятельства поступления шлема в музейное собрание установить не удалось. Однако известно, что уже в 1951 г. он был помещен в один из стендов музейной экспозиции. Существенные реставрационные работы с ним не проводились. В настоящее время наголовье продолжает экспонироваться в АОИКМ, вместе с другими предметами вооружения, датированными периодами позднего Средневековья и раннего Нового времени.

Информация о шлеме была впервые введена в научный оборот Л.А. Бобровым и А.К. Кушкумбаевым в 2010 г. (Бобров, Кушкумбаев, 2010, с. 34, 36, 37). Авторы данной публикации дали краткое описание конструкции и системы оформления шлема, а также предположили, что он был изготовлен ойратскими (джунгарскими, калмыцкими) мастерами (Бобров, Кушкумбаев, 2010, с. 37). В 2015 г.

Авторы выражают благодарность заместителю директора по науке АОИКМ Кунанбаевой Алме Сунгатовне, с.н.с. отдела учета и хранения фондов АОИКМ Жакуповой Дамеле Тайгаровне, н.с. отдела учета и хранения фондов Укееву Жасулан Каримулы за помощь и возможность детально ознакомиться со шлемом. 
К.С. Ахметжан отнес данное боевое наголовье к числу «казахских шлемов» (Ахметжан, 2015 , с. 51 , рис. 18,11 ; с. 53 , рис. 19,6$)$.

Целью настоящей статьи является подробное описание конструкции и системы оформления шлема ГИН 148 из АОИКМ, а также уточнение его датировки и атрибуции.

Главным методологическим основанием научных исследований, по изучению комплекса защитного вооружения (в том числе боевых наголовий) народов Евразии эпохи Средневековья и раннего Нового времени, являются принципы историзма, объективности, а также системный подход, состоящий в целостном рассмотрении совокупности объектов, при котором выясняется, что их взаимосвязь приводит к появлению новых интегративных свойств системы.

В рамках применения системного подхода к изучаемому материалу, отдельные панцирные элементы и комплексы защитного вооружения, изучаются, как обособленное и развивающееся целое, состоящее из согласованных, необходимых и достаточных для существования данной системы элементов, каждый из которых обладает способностью к самостоятельному развитию при сохранении целостных характеристик системы. В рамках системного подхода используются рациональные положения эволюционизма (изменчивость и наследственность) и диффузионизма (заимствование, перенос, смешение).

Методика обработки источников определяется задачами исследования. На этапах анализа и интерпретации материалов в оружиеведческих работах традиционно применяются морфологический, классификационный, типологический, сравнительноописательный методы, метод датированных аналогий, верификации и корреляции полученных результатов. На этапе реконструкции защитных элементов задействован комплексный подход, основанный на сопоставлении письменных, вещественных, и изобразительных источников.

По материалу изготовления шлем ГИН 148 из собрания АОИКМ относится к классу железных, по конструкции тульи к отделу клепанных, по форме купола к типу сфероконических. Общая высота наголовья - 24,5 cм, диаметр - 21,0 см (рис. 2).

Тулья шлема склепана из четырех пластинсекторов, стыки которых прикрыты узкими накладками с ровным краем и продольным ребром жесткости (ширина накладок - около
1 см.). Все четыре пластины тульи имеют механические повреждения в виде пробоин, проломов и (или) вмятин. Некоторые повреждения могут быть атрибутированы, как следы рубящих и дробящих ударов. Не исключено, что данные повреждения могли быть нанесены еще в период эксплуатации наголовья.

Верхняя часть тульи деформирована в результате чего, концы накладок, не примыкают к подвершию шлема встык, а нависают над пластинами тульи (рис. 1-3).

Элементы тульи соединены между собой с помощью металлических заклепок. Головки заклепок на внешней стороне шлема (на поверхности пластин и накладок) более или менее тщательно зашлифованы. Часть заклепок, соединяющих пластины тульи между собой, снабжены подпрямоугольными железными подложками на внутренней стороне купола шлема (рис. 4).

Пластины тульи незначительно перекрывают друг друга, благодаря чему стыковочные швы имеют три слоя защиты (два листа пластин тульи, поверх которых располагается вертикальная накладка с ребром жесткости). Накладка на тыльной стороне шлема удалена, из-за чего швы тульи частично разошлись (рис. 5).

Дополнительным фиксатором пластин тульи являются два узких железных обруча опоясывающих шлем на некотором расстоянии друг от друга (рис. 3). По своему оформлению, как нижний («височный»), так и верхний («лобно-затылочный») обруч весьма напоминают вертикальные накладки, прикрывающие стыки пластин тульи шлема. Так, в частности, они имеют ровный край и продольное ребро жесткости, а также схожую толщину и ширину (рис. 1-3). Оба обруча являются составными. К сожалению, с левой стороны шлема, фрагменты обручей удалены (рис. 4; 5), однако сохранившиеся элементы позволяют предположить, что верхний («лобно-затылочный») обруч состоял из трех, а нижний («височный») - из четырех частей.

Так как нижний конец вертикальных накладок не перекрывает обручи, а крепится встык, стыковочный шов пластин тульи, между верхним и нижним обручем, остается не прикрытым. Для его защиты мастер использовал дополнительные короткие железные накладки с ребром жесткости. Из четырех коротких накладок до нашего времени дошла только одна - на правой стороне наголовья (рис. 3). Однако на наличие аналогичных конструк- 
тивных элементов на других сторонах шлема свидетельствуют одинарные сквозные отверстия на налобной, затылочной и левой боковой частях наголовья (рис. $2 ; 4 ; 5)$.

Узкий обруч вместе с вертикальными накладками, прикрывающими стыки пластин тульи, образует своеобразный «каркас» шлема. Последний не только фиксирует элементы купола между собой, но и выполняет функцию ребер жесткости (то есть усиливает конструкцию наголовья), защищая, в том числе, самые уязвимые места тульи - стыковочные швы.

К налобной части шлема приклепан так называемый «коробчатый» козырек (ширина - 1,5 см), состоящий из узкой горизонтальной пластины - «полки» и вертикального «щитка» (рис. 1-4). Удлиненно-овальная «полка» козырька имеет гладкую поверхность. «Щиток» украшен по своему верхнему и нижнему краю продольными линиями. В его боковые лопасти (отделенные от основного поля «щитка» вертикальными желобками) вбиты заклепки, соединяющие козырек с куполом шлема (рис. 1-3). Вертикальное ребро жесткости по центру «щитка» выражено крайне слабо и визуально почти не фиксируется (рис. 6).

Венчает шлем двухчастное навершие состоящее из цилиндрического подвершия (пластины-основания) и фигурной трубки-втулки для плюмажа (рис. 1-5). Подвершие шлема выковано в виде «наперстка», нижний край которого оформлен остроугольными фестонами. Центральная часть цилиндра украшена горизонтальными полосами, выполненными в технике гравировки. Трубка-втулка (высота - 5,5 cм) изготовлена в виде миниатюрного «горшка» или «вазы» с широким низким горлышком (рис. 1-5). Навершие крепится к тулье с помощью специального штифта и бляхи на внутренней стороне купола шлема (рис. 7).

Вдоль нижнего края тульи шлема пробиты сквозные отверстия, в которые вставлены фигурные фиксаторы бармицы наголовья (рис. 1-5; 7). Последние выполнены в виде плоских бляшек характерной А-образной формы. В отверстия на бляшках, вероятно, продевался металлический прут, к которому подвешивалась бармица. В противном случае, через указанные отверстия в пластинках могли пропускаться тонкие ремешки или завязки бармицы, с помощью которых она крепилась к наголовью. Анализ бляшек пока- зал, что они были выполнены одновременно с другими элементами шлема и не являются позднейшим добавлением (рис. 1-5; 7).

Система крепления защиты шеи позволяет предположить, что в своей первоначальной комплектации шлем мог быть снабжен кольчатой, пластинчато-нашивной или стеганой бармицей различных видов покроя. Дошедшие до нашего времени подлинные образцы центральноазиатского защитного вооружения свидетельствуют, что в ходе эксплуатации шлема, оригинальные бармицы (в случае необходимости) могли снабжаться новыми конструктивными элементами, усиливаться, реконструироваться, неоднократно ремонтироваться и, даже, заменяться на принципиально иные виды защитных элементов (Бобров, 2009, с. 251-254; Бобров, Худяков, 2011, с. 43-52).

Наголовье ГИН 148 из собрания АОИКМ может быть датировано и атрибутировано на основании особенностей конструкции и системы оформления тульи и шлемовых элементов.

Клепаные железные шлемы с четырехчастной тульей, узкими ребристыми накладками с ровным краем, узким выпуклым обручем, цилиндрическим подвершием с трубкойвтулкой для плюмажа являются популярной разновидностью боевых наголовий номадов Центральной Азии эпохи позднего Средневековья и раннего Нового времени. Для более ранних исторических периодов подобные шлемы, в целом, не характерны (Горелик, 1983 , с. 262; Бобров, Худяков, 2008, с. 426, 432; Ахметжан, 2015, с. 51, 53).

Наряду с тульей, важным датирующим признаком шлема является «коробчатый» козырек, состоящий из «полки» и «щитка». Козырек данной конструкции является традиционным элементом оформления боевых и парадных наголовий монгольских и тюркских кочевников Центральной Азии XV-XVIII вв. (LaRocca, 2006, с. 73-75, 77-79, 91, 99; Бобров, Худяков, 2008, с. 418, 426, 432, 440-444, 446, 447, 450-452; Анисимова, 2013, с. 276, 277; Ахметжан, 2015, с. 51, 53).

Металлические, деревянные и костяные трубки-втулки для плюмажа, выполненные в форме миниатюрного «горшка» или «вазы», наиболее часто встречаются на боевых наголовьях кочевников Казахстана и сопредельных территорий XVII-XVIII вв. (Бобров, Кушкумбаев, 2010, с. 35; Ахметжан, 2015 , с. 21 , рис. $21,1,6,7,9$, с. 61 , рис. $23,4,5$; 